\title{
Purezza e meticciato: the Italian colonial novel and the (re)production of Italian whiteness
}

\author{
Francesco Casales* \\ Department of Political and Social Sciences, University of Pavia, and Laboratoire d'Études Romanes, \\ University of Paris 8 Vincennes-Saint-Denis
}

(Received 30 December 2019; final version accepted 8 June 2020)

\begin{abstract}
This essay focuses on the racialising devices that characterise some Italian colonial novels. Specifically, it looks at two novels of the late 1920s - Enrico Cappellina's Un canto nella notte. Romanzo coloniale and Guido Milanesi's La sperduta di Allah with the aim of highlighting the continuities and discontinuities between the racist models they endorse. A critical close reading of the texts reveals the degree of interconnection between segregationist and inclusivist interpretations of the cross-racial colonial encounter in the first half of the ventennio. With this perspective, the 1936 imperial turning point, even though critical on the institutional level, appears less so in the cultural field of racist production.
\end{abstract}

Keywords: Italian colonialism; colonial literature; racism; meticciato; cultural representations.

\section{Introduction}

La letteratura non è che un sotto-genere dell'attività burocratica. (Literature is only a sub-genre of bureaucratic activity.)

(Celati 1978, 24)

In a recent article Benedetta Zocchi pinpoints the difference between liberal and imperial racism as the shift of interest 'from the destiny of the Africans to the destiny of Italians' (Zocchi 2019, 21). Basically, the discontinuity between these two forms of racism, considered as fundamentally incompatible, is to be found in the distinction between hetero-referential and self-referential determinations of racial difference (Guillaumin 1992; Giuliani 2019). ${ }^{1}$ Zocchi stresses the importance of the 1936 imperial turning point in moulding Italian racist discourse. Even though, with some relevant exceptions, this distinction is well confirmed in terms of political action (e.g. Barrera 2003; De Napoli, 2009; Gabrielli 2004-2005; Sorgoni 1998), when the focus is moved to the cultural field, edges become progressively more blurred.

The objective of this work is to analyse some cultural products made before the 1936 imperial turning point with the specific aim of highlighting the degree of conflict within Italian colonial racism. In order to do so, I will try to locate some of the mechanisms of (re)production of a national and racial masculine white identity in the context of Italian Fascist colonialism. My point of access is the romanzo coloniale and, more specifically, its representations of miscegenation.

My argument will be deployed in four sections. In the next few pages I will try to outline the methodological starting points for my analysis. In the second section, the material conditions of

*Email: Francesco.casales01@ universitadipavia.it

(C) The Author(s), 2020. Published by Cambridge University Press on behalf of the Association for the Study of Modern Italy. This is an Open Access article, distributed under the terms of the Creative Commons Attribution-NonCommercial-ShareAlike licence (http:// creativecommons.org/licenses/by-nc-sa/4.0/), which permits non-commercial re-use, distribution, and reproduction in any medium, provided the same Creative Commons licence is included and the original work is properly cited. The written permission of Cambridge 
existence of the colonial novel as a genre will be briefly sketched. The third and fourth parts will take into account the conflicting ideologies in two specific colonial novels, set respectively in Eritrea and in Libya: Enrico Cappellina's Un canto nella notte. Romanzo coloniale (1925) and Guido Milanesi's La sperduta di Allah (1927a).

As regards the two different locations of the novels, it should first be noted that the Eritrean and Arab populations were understood differently throughout the entire Italian colonial experience overseas. In this contribution that difference may appear underestimated, but this should be attributed to the particular focus of my study, rather than to its unimportance. At the core of my analysis, in fact, stands the basic opposition between indigenous women and colonising men, a pattern easily identifiable in both narratives, whether concerned with northern or sub-Saharan Africans. I do not intend to reproduce a flattened colonial gaze over non-European populations, but rather to deconstruct one of the many devices that stimulated the practices of colonial dominion. ${ }^{2}$

\section{(Re)productive devices}

A central concept of my argument will be that of production. In one of his famous Six Walks in the Fictional Woods, Umberto Eco highlighted that:

Not only did [the author] ask her readers to collaborate with her on the basis of their competence concerning the actual world, and not only did she supply part of that competence, and not only did she ask them to pretend to know things about the real world that they did not know, but she even led them to believe that the real world was endowed with items which are not in fact part of its actual furnishing (Eco 1994, 96).

The author is therefore taken as a double producer: both of the reader and of the narrative space. ${ }^{3}$ Not dissimilarly, Edward Said argued about the inner functioning of orientalist knowledge:

Everyone who writes about the Orient must locate himself vis-à-vis the Orient; translated into his text, this location includes the kind of narrative voice he adopts, the type of structure he builds, the kinds of images, themes, motifs that circulate in his text - all of which add up to deliberate ways of addressing the reader, containing the Orient, and finally representing it or speaking on its behalf (Said 1978, 20).

In this case, the stress is on the density of knowledge allowing Europeans to actually speak about the Orient. As a matter of fact, the exoticising process is the result of the diachronic and synchronic cooperation - both with other texts and with the reader - of images, knowledge, ideologies, and imaginaries. The production of the Other, whether in spatial, cultural, or anthropological terms, might ultimately turn into a radical epistemological invention (Mudimbe 1988). ${ }^{4}$

Connected to this, I adopt the perspective according to which not only 'the pleasure of the text' (Barthes 1973), but 'the very existence of texts' (Eco 1979, 3) is linked to their cooperative nature. The communicative act cannot exist outside the relationship between a sender and a receiver, inasmuch as that relation is simultaneously produced by and producer of itself. Therefore, I implement a viewpoint which sees the communicative act as a process tending to (re)produce a specific hierarchical asset within society through what might be considered a cluster of different, everconflicting ideologies (Hall, 1991). In other words, I am here referring to the power of 'interpellation' of the text (Althusser 1976). ${ }^{5}$

To assume the point of view of the (re)productive character of the text, nonetheless, does not mean to interpret its foundations as monolithic. Conversely, looking at the functionalities of the text allows a lateral reading of its ideological contents. Locating this standpoint in the historical context means to recognise the contradictory nature of Fascist racism, a point of view widely shared among scholars (e.g. Cassata 2011; De Donno 2006; Giuliani 2019). The originality of my 
contribution in respect to the secondary literature lies in the access points from which I approach this problem. Firstly, I look at this relation through the lens of the representation of meticciato. Miscegenation, in fact, was a transverse issue in most strands of colonial racism (Gillette 2001; Poidimani 2009). Its over-representation testifies to the extent and the diffusion of anxieties over the purity of the white race. Whether interpreted in the light of the partial refusal of a too strict biological interpretation of race or in the terms of a physical repulsion about racial impurity, miscegenation results in a prism through which it is possible to look at the shifts in the ideological conflicts in the Italian racist debate. Secondly, as shown in the next section, I look at the colonial novel in terms of the popular novel, and therefore as a primary source capable of demonstrating both the intention of the producer and the expectations of the reader.

\section{The unpopularity of a popular novel}

Given the premises delineated above, it should be clear that, to understand the phenomenon of the colonial novel, it is critical to locate the target audience that writers, publishers, and sponsors had in mind. In other words, it is necessary to detect the material condition of existence of the communicative process.

First of all, it should be remembered that the reading public of the time was not substantial. In 1921 illiteracy in Italy still stood at 30 per cent of the population (McLean 2018, 8), a figure which would slightly decline in the following five years, reaching 21 per cent in 1927 (Tranfaglia 2000, 24). However, as the analysts of the time were well aware, even among the literate population the consumption of published material was very limited (Ciarlantini quoted in Tranfaglia 2000, 244). In this context novels and romances played an even more secondary role to other literature. Between 1919 and 1930 the percentage of published novels more than doubled, even though at the height of production they did not amount to more than 12.21 per cent of overall publication (Tranfaglia 2000, 300). ${ }^{6}$

Nevertheless, some novels became bestsellers. As reported by Michele Giocondi, more than 50,000 copies - the minimum for a bestseller -were printed of several novels: in some cases this was even 300/400,000 copies (Giocondi 1978, 17-23). So a certain reading public did actually exist. According to Giocondi, the genres this public was interested in were basically six (in descending order of success): romantic, 'daveroniano', pornographic, fascist-heroic, bourgeoisrealist, and comic. ${ }^{7}$ Notably, there is no explicit reference to the colonial novel, even though some novels of the canon are subsumed under the 'fascist-heroic' category. ${ }^{8}$

To my knowledge, the first time the colonial novel as such is considered among the plethora of popular novels of the time is in Maria Pagliara's contribution to the collective volume I Best-seller del ventennio (Pagliara 1991). ${ }^{9}$ In her essay the Italian scholar considers the colonial novel as a propaganda project aimed at diffusing ideology via popular literature - a project that actually met consistent failure. ${ }^{10}$ The main sources usually employed to demonstrate this point are the two 'surveys on colonial literature' published respectively in 1931 and 1933 in L'Azione coloniale.

The first of these (1931), aimed at authors, mainly demonstrates the attempts made by each novelist to be considered the primary initiator of the genre and, at the same time, the only one actually entitled to write on such issues. ${ }^{11}$ Conversely, the second 'survey', launched on 6 July 1933, was directed at publishers. It consisted of five questions, the most interesting of which - at least for our purposes - was concerned with the actual success of the publications. The responses were invariably negative. The publisher Giacomo Agnelli, for example, reported 'very little interest in the public, certainly not designed to induce people to publish works of this kind' (6 July 61933,3$){ }^{12}$ Treves - probably the most successful publisher of the time (Decleva 1993) - added a further 
point of view, dragging in the role of the regime: 'But we would perhaps be straying from the truth if we said that these remarkable works usually win a large readership. Their diffusion depends almost entirely on the initiatives and effort put in by the Istituto Nazionale Fascista di Cultura' (31 August 1933, 3).

However, despite their probable commercial failure, almost 150 colonial novels were published within about twenty years (1921-43), ${ }^{13}$ an important fact given the substantial lack of a stable reading public at the time. One possible factor to explain this apparent contradiction - the commercial failure and the continuation of the editorial project - is governmental interest in the issue.

Since the very beginning of the Fascist government, literature had played a critical role in the 'bonifica integrale' project and the production of the 'new man' (Ben-Ghiat 2001). As much as scholarly education, literature was seen as one of the main channels through which to directly address individuals and include them in the cultural fabric of the nation (McLean 2018). The very act of reading, in particular, underwent a major transformation, from a bourgeois, solitary activity to a collective one (Scotto Di Luzio 1996). This is why, in order to understand Fascist political culture, it is necessary to look primarily at publishing output during the period (Galfrè 2005).

The colonial novel, in this sense, is epitomic. In relation to this genre, the state did not only act as a commissioner - a role that was perfectly clear to the publishing houses (Scotto Di Luzio 1996, 10) but also as a patron to the authors. In 1925, the Ministry of the Colonies launched a 10,000-lire prize for the best romanzo coloniale written up to that point. The trophy was won by the former colonial soldier Mario Dei Gaslini with his Piccolo amore beduino (1926), and his win brought him other advantages. Mainly, it resulted in a never-ending source of legitimacy and free advertising. 'L'idea coloniale' - supplement to the more famous 'L'Idea Nazionale', gave ample significance to the award, and depicted the novel as the new 'beginning for Italian colonial literature' (quoted in Tomasello 2004, 153). The prize, moreover, was pretentiously mentioned on the title pages of the first edition of the novel, and readers were also reminded of it in the bibliographical note preceding the text of a later work, Natisc, fiore dell'oasi (1928).

The popular nature of the colonial novel, as a consequence, acquired a new meaning: it was not popular in reference to its material success, but in relation to the will of those who produced it. In this sense, the ideological objectives of authors, publishers, and state actors, were the hidden drivers of the genre.

\section{Paternity: patterns of action}

One of the most frequent propaganda themes of the 1920s was the Fascist reconquest of Libya (Labanca 2002, 137-49, 240-6). Hundreds of articles, short stories, novels and movies recounted the bravery of the Italian army, the weakness and cowardice of the anticolonial fighters, the leading roles of Marshal Graziani and General Badoglio. Colonial novels were no exception. In particular, books by former colonial soldiers - such as Dei Gaslini or the Spahi officer Gino Mitrano Sani attracted publishers' attention (Boddi 2012; Tomasello 2004). However, the influence of the Libyan war was not limited to those novels explicitly written to narrate it. More generally, between 1925 and 1930, the first wave of massive colonial propaganda - focussing also on Eritrea, Somalia and the Dodecanese - contributed to the preparation of a suitable environment for colonial novels in general (Giuliani Caponetto 2015).

Moreover, the late 1920s saw a considerable increase in centralisation by the regime (Gentile 2018), at the apex of which came the enforcement of the bonifica integrale project (Ben-Ghiat 
2001). In this context, Mussolini's Ascension Day speech of 1927 marked 'the definitive sunset of early Fascism and the abandonment of its anti-traditional, anti-matrimonial, Futurist, and anarchical orientation in favour of continuity with the virilist tradition of conservative nationalism' (Giuliani and Lombardi-Diop 2013, 40). In other words, it is at this point that Fascism eventually adopted the pro-ruralist, pro-natalist, and orthogenetic project already began with the foundation of Opera Nazionale Maternità e Infanzia in 1925, establishing a perfect continuity of direction in its presentation of race and gender roles (McLean 2018, 25).

The two novels analysed in the following pages were conceived, written, and published exactly at this juncture. Enrico Cappellina's Un canto nella notte. Romanzo coloniale, published in 1925, was soon followed, in 1927, by Guido Milanesi's La sperduta di Allah. ${ }^{14}$ Although they originated in the same context, these two novels proposed conflicting narratives of Italian colonialism and of Italian masculine identity and its role in both colony and metropole. Where Cappellina viewed the colonial encounter as rooted in the Europeans' civilising mission, Milanesi argued for a form of colonialism of dominion, justified by the natural right of superior nations. Recalling Zocchi's incisive definition, we can say that while Cappellina was concerned with 'the destiny of the Africans', Milanesi was only interested in the fate of the Italians (Zocchi 2019, 21). This distinction perfectly mirrored the legislative and institutional definitions of Italian citizens and colonial subjects (Bonmassar 2012; De Napoli 2009). In other words, where Cappellina imagined meticci (those of mixed race) to be Italians by right, Milanesi strongly refuted this option and firmly relegated mixed-race individuals to indigenous society. As a consequence, these two novels - even though forming a minuscule part of the overall number of colonial novels - represent a valuable access point to the complexity and contradictory nature of Fascist racism in the late 1920s.

Renato Severi, the main character of Un canto nella notte, is a First World War veteran. He has fought bravely and when he returns from the front, he discovers his mother is dead and his fiancée has left him. Moreover, the political situation in Italy does not satisfy his proud, warlike spirit. Fearing the Fatherland might pull him down in its decadence he decides to move to Eritrea, hoping for a new life. There, he eventually meets the woman to whom he was once betrothed. But he also meets Medin, a naïve young indigenous woman with whom he starts a relationship that will culminate in his fathering a child. As Renato is about to leave for Libya to fight the anti-colonial rebels, Medin confesses she is pregnant. Renato has no doubts: he will recognise the baby as his own and name him after himself. The offspring of a white man and a black woman will, in fact, be a white by right. Severi is not only moved by a strong sense of duty ('man of conscience, he felt that a great new responsibility was weighing on him' [281]); he has an affective connection with the baby. On the doorstep of his house, about to depart for Libya, he whispers to Medin: 'I am leaving in you more than my life' (Cappellina 1925, 279). Despite his commitment, Severi will never meet his own son - he will die heroically in Libya. However, following a pattern of behaviour already documented in scientific literature, the child will not stay with his mother (Sorgoni 2001). On the contrary, he will be cared for by Renato's former betrothed and taken to Italy, to 'the environment he rightfully belonged to in virtue of his father's name' (Cappellina 1925, 319). ${ }^{15}$

The protagonist of La sperduta di Allah, Ugo Albertenghi, is, in this sense, a mirror image. He is an Italian colonist as well, a First World War veteran, and the father of a meticcio boy. The colonial setting, however, is Libya, prompting the author to reflect on Italo-Arab relations. Although considered racially closer to their European masters than sub-Saharan Africans, Arabs were represented as even less inclined towards integration/civilisation (Airelli 2010; Goglia 2005). Their culture and religion, then, if accepted as such - which is to say, recognised as a valid, complex structure of identity - resulted in a much greater obstacle to colonial communication than the total lack of civilisation of sub-Saharan populations. Therefore, the sexual relationship between 
Ugo Albertenghi and the Libyan woman Neschma could not result in the continuation of Italian stirpe (lineage). The meticcio baby born out of their relationship could not be Italian. Killed by his Arab grandfather - incapable of accepting a half-Italian, half-Arab grandchild - the baby is buried in the necropolis of Gadames. Albertenghi makes a pilgrimage to the headstone, which is surmounted by a star and crescent, and bears only his son's Arab name - Ahmed Ben Uhg. He realises that he feels no connection to his dead son: 'Even the memory of that son was no longer left to his father. The land of Allah had received him but had given him the mark of the children of Allah in order to make them Saharan dust' (Milanesi 1927a, 329).

These two novels are dominated by two issues in relation to mixed-race babies. On the one hand, there is the question of citizenship: are meticci to be considered Italians or indigenous? Is their race determined by their father's whiteness or by the non-Europeanness of their mother? As is clear, this issue went far beyond the personal beliefs of the authors and was deeply rooted in the fabric of Italian presence in the colonies, as a look at the changes in the civil status of the meticci over time confirms. ${ }^{16}$

On the other hand, there is the issue of affection. Could an Italian, European individual feel any connection towards his own meticcio son? As is clear, Cappellina and Milanesi gave two completely different answers to these questions. However, moving the focus from the actual meticci to the condition which gave them birth - the relation between the white man and the black/Arab woman, and the question 'can a European feel any connection to a non-European person?' means that the arguments employed by the two authors end up extremely similar.

\section{'A new soul': the interracial sexual encounter}

According to Luciano Zuccoli, one of the founding fathers of the Italian colonial novel, the specificity of this genre in relation to the more general exotic, adventure, and travel novels, lies in the authors' interest in representing the indigenous psychology rather than the European experience of the colonial encounter:

I believe that whoever reads a colonial novel and not a simple travel report, has the right to be served differently. We would like to know not the psychology of the European in the Sahara or in Haiti ..., but that of the natives, directly, precisely, intimately and completely - their customs, passions, and their days of drama (Zuccoli 1923, vii).

Such an attempt, according to Zuccoli, was typical of the British colonial novel, and specifically of the work of Rudyard Kipling. At least theoretically, Italian colonial novelists accepted this guideline, but apart from a few exceptions, this did not result in a proliferation of non-European main characters. ${ }^{17}$ At best, the attention given to 'indigenous populations' produced an increase of non-European secondary characters, mainly female ones.

As stressed by several scholars, female characters are the critical access point to the racist structure of colonial novels (Boddi 2012; Giuliani Caponetto 2015; Lenci 2001). First and foremost, the narrative structures of these stories provide clues to the stereotypes with which the image of the colonial Other was built. Along with movies, short stories, comic strips, poster designs and so forth, colonial novels are an incredibly fertile archive of stereotypes of colonial women (Faloppa 2013; Giuliani 2019; Pinkus 1995). Secondly, the ways in which native women are represented provides the negative of the positive strategies used to build the identity of white men. Through the narrative opposition to subaltern characters the virtues of the dominant ones were defined as (universal) moral and political models (Stefani 2010). Finally, the depiction of the encounter between white man and indigenous woman can clearly be seen as a metaphor for the colonial encounter as a whole (Deplano 2012). It provides evidence for the authors' interpretations 
of the ways colonial expansion is justified and 'allows light to be shed on the main symbolic objectives pursued by the regime' (Bonavita 2009, 78). In this sense, an analysis of the narrative functions embodied in these two kinds of characters might help to illuminate the ways in which interracial relationships were perceived and normativised. ${ }^{18}$

The two main white characters in Un canto nella notte and La sperduta di Allah, Renato Severi and Ugo Albertenghi, share most traits. Both men, first of all, are disgusted by the degeneration of their own land. Just returned from the front, Renato Severi is faced with an unbearable situation. On the personal level, he has lost his mother and his fiancée; on the political level, he witnesses the emergence of anti-patriotic, socialist movements, 'a terrible disturbance of consciousness contaminated by a pernicious plague' (Cappellina 1925, 2). As a solution, he decides to move to the Eritrean colony to 'begin a new life in a different environment' (Cappellina 1925, 2).

Ugo Albertenghi, who is already in the colony when the reader meets him, is moved by similar feelings. After having left Libya to fight on the Karst front, Albertenghi is faced with the degeneration of the country for which he has made so many sacrifices. Specifically, he is struck by the feminist movements, seeing them as the ultimate attack on the established order. Speaking with his former betrothed Doretta Doraudi, he is disgusted by her, by this 'woman sprung out of the postwar society' (Milanesi 1927a, 213):

His spirit was taken away from there, far from that postwar creature, stripped of everything that once shaped the ideal attraction of women and who, under the patina of fashion, luxury and sophistication, regained, too easily, her wildness. Female again: the instrument of the senses as in all races, even the most inferior ones (Milanesi 1927a, 219).

Once again, removal from this unhealthy environment is seen as the only alternative to degeneration. So Albertenghi decides to go back to Libya, where 'he felt an exact correspondence between his spirit and the rough, elementary, schematic landscapes he was surrounded by, created to offer the strong ones a free space for all the images of their future and make them reality' (Milanesi 1927a, 118).

In other words, both Severi and Albertenghi strategically move to the space of the colony with the aim of limiting their individual degeneration. Embittered by the 'tragic hilarity' of the Versailles treaties (Milanesi 1927a, 209), they apparently give up their duty towards the imagined community of the nation. ${ }^{19}$ They renounce collective political action and take shelter in their own individual autonomy. At the same time, though, as soon as Fascism emerges, they will immediately regain trust in mass action. And so, while Severi will volunteer for Libya and eventually die in the endeavour, Albertenghi will totally dedicate himself to Fascism, defined as 'such a great thing that the history of our days, tumbling already like a torrent towards the abyss, will be clearly stopped and will be compelled by a unique miracle, to go back to its source' (Milanesi 1927a, 229).

Before that moment, however, the homeland's degeneration has already followed the protagonists to the colonies, embodied in the sensuality of native women. ${ }^{20}$ Both Severi and Albertenghi will resist these temptations, but through two different strategies. Severi, on the one hand, overcomes the sexual danger through civilisational rhetoric. As he states in the first pages of the novel:

If one day I were to take one of these little savages with me, I would not remove her from her environment, as so many do, exclusively for a selfish insane lust, to take her to the highest peak, from which beauty may be enjoyed but the fall becomes more likely and more disastrous. Instead, I would try to give her a new soul, sensitive and strong at the same time (Cappellina 1925, 51).

Renato Severi is here reconfirmed in his superiority through contact with the inferior Other. Medin, being both a woman and African, must obey her lord and, through this relationship, elevate herself 
to a higher societal level. The Italian civilising mission, therefore, is here metaphorised. Just as Severi is responsible for Medin's spiritual growth, so the Italian dominion over East Africa is destined to raise the spirit and civilisation of the colonial subjects.

In contrast, Albertenghi surrenders to Neschma's sensuality, ultimately experiencing a deep disgust for her inferiority. There is no attempt at civilisation, since he believes that he could 'expect from her nothing but the schematic ideas of a primitive mind' (Milanesi 1927a, 286). The lack of a civilising mission will eventually frustrate the very foundations of their relationship: 'His love for Neschma was but an exaltation of his own flesh, without any corresponding nurture of the spirit; he lived only for the poisonous essence of voluptuousness; an ecstatic, necessary and murderous cocaine' (Milanesi 1927a, 289). ${ }^{21}$ This representation, however, does not relate only to the narrative necessities of the novel. Rather, it is rooted in the equivocal understanding of the racial determination of Arabs. Seen on the one hand as keen to integrate and basically compatible with the Italian character, and on the other as totally alien to any possibility of civilisation, Arabs were substantially interpreted within an Orientalist framework (Proglio 2016). Consequently, they were represented in an ambiguous manner, allowing contradictory assumptions on their disloyalty and trust, submission and pride, animal sensuality and uncorruptible chastity, to coexist.

The white man's role is invariably linked to the African woman's condition. Medin, the Eritrean woman, is the modern image of the 'good savage'. She is an empty vessel waiting to be filled with civilisation:

Renato observed the sensations of that virgin soul that clearly reflected itself in the girl's eyes; and he thought that not without satisfaction he would have lifted, directed that life grown without support, without guidance and without destination, like a blind man abandoned in the light denied to him (Cappellina 1925, 71).

As a consequence, the relationship between the white man and the African woman, described as a teacher-pupil relationship, produces a new colonial subject, perfectly known to the European master: 'But then does the eye of the white master see the whole soul of the black pupil? Yes, my dear, I read in your soul because I wrote there' (Cappellina 1925, 83). This relationship, even if positive for the colonial subject, presents advantages for the dominant character as well. Through this relationship he can ultimately regenerate himself: 'I [Renato Severi], in the regenerating sun, in the solemn silence of this fascinating land, burned my burden of sad memories, and in your eyes I saw the new flame of my life igniting' (Cappellina 1925, 103).

Once again, Milanesi fills the same narrative structure with opposite values. The native woman, Neschma, is as submissive to Albertenghi as Medin is to Severi. However, Neschma's is typical of the inner submission of the Arab race: 'She reproduced the absolute submission of her race, the sense of never bothering and of knowing how to remove every shadow from the path of the Sidi and make an idle cult out of this' (Milanesi 1927a, 198). And it is exactly this strong racial determination that prevents her from converting to Christianity. The conversion, in fact, would result in a denaturing of her own being: 'Can you empty all your veins to fill them with another blood and continue to live? No: I answer no. Then why are you tormenting me with these questions? Can't you live with me without emptying my veins?' (Milanesi 1927a, 262). The only solution to this deadlock is separation. Albertenghi cannot accept Arab inferiority ('the more the violent and sinister demonstrations of Arab life amassed around him, the more he felt extraneous to them, driven out by a limitless disgust' [336]), and Neschma cannot betray her race: she must remain 'on the other side of the abyss' (Milanesi 1927a, 113).

The difference between Medin and Neschma, it might be said, is therefore articulated through a double gaze. The first is that of the white Italian man who, in Libya, recognises a difference 
impossible to overcome because it is rooted in the strength of the pre-colonial culture; in Eritrea, in contrast, colonisers disavow any legitimacy of precolonial systems and activate a strictly paternalistic, civilising rhetoric and action. The second gaze, however, is that of the white author. Cappellina and Milanesi embodied two different conceptions of racial and cultural encounter. Where Cappellina recognised the right of indigenous populations to be civilised - therefore endorsing a paternalistic form of dominion - Milanesi harshly refuted such a possibility and argued in favour of a strictly segregationist colonial society. However, this different approach to interracial encounter (whether sensual or procreative) is less rooted in the specific colonial Libyan or Eritrean environment than in an all-encompassing, flattened view of the colonies, considered as basically interchangeable.

In this perspective, the life experiences of the authors may have been critical to their literary creations. In the case of Cappellina we cannot examine this, because of the complete lack of biographical information about him. In contrast, references to Milanesi's life are easily accessible. His experience in the Italo-Turkish war of 1911-12 clearly played a major role in defining his attitude to colonial issues. Already in his first novel, the representation of Arab characters was primarily rooted in a religious understanding (Milanesi 1913). In the late 1920s, at the very moment when the 'pacification' of Cirenaica and Tripolitania was taking place, the nationalistic themes he had developed in Anthy. Romanzo di Rodi erupted violently in the political arena. Milanesi's representation of Neschma as basically compatible to Europeans if it weren't for her religious heritage, was related on the one hand to a pre-Fascist system of signification, but on the other hand it clearly owed a major debt to the representation of Sanussyya (the anti-colonial Sufi order) as the main adversary of Italian military action. To be more clear: if the ambiguity with which Arab characters were presented surely derived from the variety of images Italians gave them since the Italo-Turkish war in 1911/1912, in a new juncture, those same meanings were maintained and risignified, ultimately operating through 'revisione nella ripetizione' ('revision in repetition') (Proglio 2016, 361). Milanesi's system of reference was more rooted in contemporary propagandistic themes and in a radically ethno-centric narration, than in a desire for faithful and realistic representation.

The locations of the two novels, therefore, were meaningful in their own right, but were also strictly linked to the ideological standpoints of their literary creators. In other words, it is impossible to state unequivocally that, as regards the Horn of Africa, colonial authors employed a civilisational rhetoric or, in contrast, that they always employed a segregationist one when the narrative was set in Libya. At the same time, though, it would be naïve to assume that there was no relation between the ideological standpoints of the authors and their preference of one setting over the other. Rather, a conjunction of these two elements seems more plausible.

In conclusion, in order to get to their point, both authors develop a quite similar narrative structure. Moreover, they employ the same set of values to be found in Fascist culture in general, such as the exaltation of war, the virility of the male, and voluntarism (Griffin 2007). The production of national, racial, and gender identities, then, is obtained through recourse to a common symbolic imaginary, an imaginary built around the normative model of masculine whiteness.

\section{Conclusion}

Fascist culture never reached any real homogeneity, nor did its ideology (Gentile 1993). Rather, Fascism was able to restructure a series of antecedent mythologies into a quite ambiguous set of values, histories, and practices (Tarquini 2011). It should not be surprising that its colonial ideology was rather polymorphous as well (Deplano 2015). In general, the racist theories aimed at 
justifying colonial conquest never reached a definitive synthesis (Pisanty 2006). Aryanism, Roman imperialism, Mediterraneanism, justification by civilising mission: all these features intertwined and conflicted until the fall of the Fascist regime. ${ }^{22}$

As a consequence, it might be quite challenging to go through colonial novels in search of a precise determination of race, racism, or a colonial agenda. The colonial genre should not be expected to deliver a united perspective where there was none. Rather, it should be seen as the mirror and laboratory of the 'razzismo diffuso' (widespread racism) of the period (Labanca 2002, 412-21). Assuming such a perspective, in other words, means to recognise both the continuities and the discontinuities within the discursive texture of Italian and Fascist racisms. The representations of miscegenation, in this context, are a valuable point of access.

Even though not exclusive to Fascist racism, the 'problema meticcio' (Gabrielli 1997) assumed an outstanding importance in the political context. Especially after the proclamation of the empire in 1936, anti-miscegenation laws became the ruling norm on interracial relationships both in the colonies and the metropole. However, when we move the focus to the cultural field, such a clearcut 'before and after' distinction, between an inclusivist and a segregationist policy, cannot be sustained. The separation between the confused, partially inclusivist nature of liberal and early Fascist racism (a hetero-referential determination of difference) and the strictly biological, segregationist character of imperial racism (based on self-referential devices) did not find substantial confirmation in the wider racist discourse. Specifically, taking a close look at the liberal and early Fascist period, it can be argued that both these perspectives were very present in the cultural discourse of the time and, moreover, that they had their own specific sponsors. The novels analysed in these pages proved a valuable metaphor of the conflicting nature of Fascist racism. Even though they proposed two radically incompatible interpretations of the meticci's racial determination, they did so through a similar system of signification.

Firstly, they both dwelt on the psychological effects of the colonial encounter between white men and native women. Moreover, the narrative functions of these two types of character were almost the same in both novels. In both cases, the white man is presented as a potentially degenerated individual who finds eventual regeneration through a process of individual de-territorialisation. Conversely, the black or Arab woman is depicted as a weak character, always in need of guidance. Substantially, the woman's function in the plot is that of allowing the white man to restructure his own self-perception (and this is valid, most often in an opposite way, for the white woman as well). The white masculine identity is built through the narrative opposition with subaltern characters able to reconfirm him in his own position of superiority. The very use of subaltern characters in the overall narrative, in this perspective, is to (re)produce the conditions of the dominion exercised by the hegemonic white, masculine subject.

Secondly, the two novels unfold through a similar narrative structure. In both cases we see the de-territorialising process: the encounter with the native woman; the birth of a meticcio child; the separation. The two novels used the same language, the same structures of meaning. The signifiers employed, the narrative functions were the same. However, the ways in which they were juxtaposed and articulated gave space to different understandings. The symbolic imaginary of the colonial encounter worked through the same set of symbolic imaginaries, but in reference to different racist ideologies.

In conclusion, this article has highlighted the possibilities of considering and mobilising a genealogy of the symbolic imaginary of meticciato as more ambiguous than a clear-cut consequence of institutional actions after the foundation of the empire in 1936. Instead, there is a story to be told about the cultural battle that characterised the redefinition of Italian (Fascist) identity in the first half of the ventennio. As David Bidussa reminds us: 'If one does not want to admit 
that racism in Italy pre-existed the racial laws, one must concede that this is indicated by an encyclopedic interpretation of the contemporary political ideology, regardless of the concrete policies that a specific regime, inspired by that ideology, puts into effect' (Bidussa 1994, 15).

\section{Acknowledgements}

Every research is the result of a collective effort. I would therefore like to thank my tutors, Professor Arianna Arisi Rota and Professor Xavier Tabet, for their consistent support in helping me to carry on this study, and Professor Silvana Patriarca for her always punctual assistance. Heartfelt thanks go to Professor Paolo Capuzzo, who was the first to believe in this research. Finally, thank you to Jacopo Bonasera, Enrico Ciappi, Sarah Miclet, and Luca Nigro for having kindly read and corrected the various drafts of this work.

\section{Note on contributor}

Francesco Casales has obtained both his Bachelor and Master's degrees at the University of Bologna, respectively in Lettere Moderne (2015) and Scienze Storiche-Global Cultures (2018). Currently he is a $\mathrm{PhD}$ candidate in History at the University of Pavia (Department of Political and Social Sciences) and at the University Paris 8/Vincennes (Laboratoire d'Études Romanes). His doctoral research concerns the political and cultural history of Italian colonialism and racism through the lens of popular culture.

\section{Notes}

1. The distinction between self-referential and hetero-referential racism is widely employed in the field of race studies. Where self-referential racism is based on a definition of difference rooted in the universality of the racialising subject, hetero-referential racism is articulated in relation to the differentiation in respect to the racialised subject. In other words, where the former endorses the values of the defence of the race, the latter does not necessarily refuse interracial contacts as long as the superiority of the white race is not doubted. So is quite easy to understand why these two terms have been employed to describe imperial and liberal/early Fascist racism respectively.

2. For a valuable analysis of the different role of Arabs and Eritreans in Italian racist and colonial discourse see Airelli 2010; Barrera 2003; Proglio 2016.

3. However, we might add another competence to this same author: not only the ability of making claims to truth from what the reader does not know, but also from what the writer has never experienced. As suggested by Gianni Celati, this is one of the most effective mechanisms sustaining exotic literature (Celati 1978).

4. As it should be clear, the devices put into practice in the process of (re)production of the spaces of the Orient and Africa did not coincide. Rather, they presented an irreducible specificity. As pointed out by Gianpaolo Calchi Novati, Africa was - and still is, to some degree - 'neither Orient nor West, but 'the Other of the Other', 'Orient of the Orient', if only geography allowed for it' (Calchi Novati 1995, 32).

5. The concept of 'interpellation' defines the ideological inclusion of individuals as from the specific positions already occupied by the individuals themselves. As a consequence, subjects are not coercively (re) produced, but rather induced to recognise the positionality they occupy as the one specifically designed for them. Therefore, the power of 'interpellation' does not work irrespective of the individuals it is directed at but is continually rearticulated as so to adapt to their specificity.

6. A major issue that cannot be fully addressed here is that of the increment of translations from foreign languages, mainly English and French (see Ferrando 2019). See Antonio Gramsci's reflections on the limited success of Italian popular literature within the wider problematic of 'national-popular culture' (Gramsci 1975, XXI).

7. Giocondi's term 'daveroniano' refers to Guido Da Verona (1881-1939), an extremely celebrated author of the time, mainly known for his erotic novels, such as Mimì bluette, fiore del mio giardino (1916) or Sciogli la treccia Maria Maddalena (1920). 
8. The data reported by Giocondi are not entirely verifiable, given the scarcity of information provided about the methodology employed in the course of the research. However, his work is extremely valuable in respect to the number of novels he makes reference to. The colonial novels subsumed under the 'fascist-heroic' category are Milanesi, Sancta Maria (1936); Vergani, Io povero negro (1928); Milanesi, Figlia di re (1923); Milanesi, L'ancora divelta (1923); Corra, Sanya la moglie egiziana (1927); Bacchelli, Mal d'Africa (1935).

9. In the seminal work of Giovanna Tomasello (1984), in fact, colonial novels are interpreted as 'high literature', even though the popular inspiration of some of the authors is taken into account.

10. Bonavita 2009, Boddi 2012, Giuliani Caponetto 2015 and Labanca 2002 (244-5) also broadly follow this analysis.

11. Notable, in this context, is the quarrel between Arnaldo Cipolla and Luciano Zuccoli about the amount of time spent in the colonies by the latter; more generally, it is interesting to note how the debate mainly gravitated towards the existence of a colonial 'writer' rather than towards the value of colonial 'writing' (see Tomasello 2004).

12. All translations are my own.

13. Arnaldo Cipolla's La cometa sulla mummia (Florence: Bemporad) was the first of these, and Emilia Sbrana Cacace's L'ascesa alla luce (Verbania: Airoldi) the last.

14. Enrico Cappellina (1889-?) wrote two colonial novels: Un canto nella notte. Romanzo coloniale and Tzegai. Danzatrice del Tigré (1931). He is scarcely considered in the secondary literature on Italian colonial novel, the only reference to him appearing in Massimo Boddi (2012, 61-3), Laura Ricci (2005, 95$151)$ and in Giovanni S. Santangelo $(2017,53 ; 61)$. His work, however, would enjoy a certain success after the Second World War, thanks to his writings on his conversion to Catholicism (Cappellina 1952). Guido Milanesi (1875-1956) was a prolific author of military, exotic and colonial novels. Well represented in studies on the Italian colonial novel (e.g. Bonavita 2009, 32-9; Boddi 2012, 63-70; Proglio 2014, 91-3; Tomasello 2004, 154-5) and popular literature in the 1920s (Giocondi 1978, 10, 16-23; Pagliara 1991), he would enjoy a wide success even after 1945. Allegedly, he was even supposed to have received the Nobel Prize for Literature in 1918 - year in which the prize was suspended (Milanesi 1927b, vii).

15. Cappellina's commitment to the inclusion of meticci within the racial fabric of the Italian nation is confirmed in his second colonial novel, Tzegai, danzatrice del tigrè (1931) whose main character, Stifanos Arra, is a meticcio landowner, son of an Eritrean woman and of an Italian soldier killed at Adwa.

16. Until 1917, abandoned meticci children were denied access to Italian citizenship as much as they were excluded from Eritrean indigenous society (Barrera 2005, 105). However, if they had not been abandoned by their Italian fathers these babies were given citizenship and, in some cases, even separated from their mothers and brought to Italy (Sorgoni 2001). Notwithstanding this situation, the living conditions of meticci remained critical (De Napoli, 2009). Things, though, were bound to change. In 1933 a new law was issued (Ordinamento organico per l'Eritrea e la Somalia), a law that, on one hand, improved the chances of abandoned meticci obtaining Italian citizenship, but, on the other, introduced both cultural and biological tests of 'Italianness'. In other words, at the moment when meticci were basically recognised as Italians, they were reminded of the instability of their own identity, ultimately paving the way for the eventual promulgation of the biologically informed anti-miscegenation laws of the late 1930s.

17. Such exceptions might be identified in Cappellina, Tzegai, danzatrice del Tigré (1931), Vergani, Io, povero negro (1928) or Vittorio Tedesco Zammarano, Ahuèr, mio sogno (1935), to cite three of many.

18. As has been competently shown by Zaccaria (2012) and Chelati Dirar (2008), the colonial encounter was metaphorised through the representation of Askari soldiers as well. However, in exotic-erotic colonial novels - such as those here analysed - this specific device is not really activated. Interesting clues about the perception of Askari soldiers in colonial literature, however, can be found in children's stories, such as Rosolino Davy Gabrielli, Il piccolo Brassa. Romanzo coloniale per i giovani (1928), Alfredo Fabietti, L'amba selvaggia. Avventure sui laghi d'Etiopia (1937) and Andrea Festa, L'ascaro libico: racconto di vita coloniale (1931).

19. The trope of the 'imagined community of the nation' can be retrieved in Giuliani's reappraisal of Benedict Anderson's theorisation (Giuliani 2019).

20. On the role and function of the myth of the 'black Venus' the best works of reference are still those of Sandra Ponzanesi (2005) and Barbara Sorgoni (2003).

21. Interestingly, the reference to cocaine is not limited to interracial relationships. It is also employed in depicting European degeneration: 'Funeral halls were the nightclubs, torches the electric chandeliers, 
priestesses the half-naked and painted women, priests the euphoric young sons of idleness and cocaine, obituaries the governments, funeral marches the tango, the foxtrott and the shimmy. Signs of a dissolving decrepitude appeared everywhere, and it seemed that Europe, having completed its historical cycle, fatally resigned itself to becoming a desert scattered with ruins like those regions of Asia where once there were splendid royal palaces and opulent metropolises, today silent paradises of snakes' (Milanesi 1927a, 225).

22. And even after that date. In relation to the systemic permanence of Italian colonial structures see Morone 2011. As far as imperial formations are concerned, see Deplano, Mari and Proglio 2014; Hom 2019; Lombardi-Diop and Romeo 2012.

\section{References}

Airelli, N. 2010. Fascist Italy and the Middle East, 1933-40. New York: Palgrave Macmillan.

Althusser, L. (1970) 1976. 'Idéologie et appareils idéologiques d'Ètat'. In Positions (1964-1975), edited by L. Althusser, 67-125. Paris: Les Éditions sociales.

Bacchelli, R. 1935. Mal d'Africa: romanzo storico. Milan: Mondadori.

Barrera, G. 2003. 'The Construction of Racial Hierarchies in Colonial Eritrea: The Liberal and Early Fascist Period, 1897-1934'. In A Place in the Sun. Africa in Italian Colonial Culture, edited by P. Palumbo, 81-115. Berkeley: University of California Press.

Barrera, G. 2005. 'Patrilineality, Race, and Ethnicity: the Upbringing of Italo-Eritreans During Italian Colonialism'. In Italian Colonialism, edited by R. Ben-Ghiat and M. Fuller, 97-108. New York: Palgrave Macmillan.

Barthes, R. 1973. Le plaisir du texte. Paris: Éditions du Seuil.

Ben-Ghiat, R. 2001. Fascist Modernities: Italy 1922-1945. Berkeley: University of California Press.

Bidussa, D. 1994. Il mito del bravo italiano. Milan: Il Saggiatore.

Boddi, M. 2012. Letteratura dell'impero e romanzi coloniali (1922-1935). Marina di Minturno: Caramanica.

Bonavita, R. 2009. Spettri dell'altro. Letteratura e razzismo nell'Italia contemporanea. Bologna: Il Mulino.

Bonmassar, M. 2012. Razza e diritto nell'esperienza coloniale italiana. Rome: Sensibili alle foglie.

Calchi Novati, G. 1995. Dalla parte dei leoni. Africa nuova, Africa vecchia. Milan: Il Saggiatore.

Cappellina, E. 1925. Un canto nella notte. Romanzo coloniale. Bologna: Cappelli.

Cappellina, E. 1931. Tzegai, la danzatrice del Tigré. Bologna: Cappelli.

Cappellina, E. 1952. Un solco sull'infinito. Dall'ateismo alla fede. Rome: Edizioni Paoline.

Cassata, F. 2011. Building the New Man. Eugenics, Racial Science, and Genetics in Twentieth Century Italy. Budapest-New York: Central European University.

Celati, G. 1978. 'Situazioni esotiche sul territorio'. In Letteratura esotismo colonialismo, edited by A. Licari, R. Maccaganani and L. Zecchi, 9-28. Bologna: Cappelli.

Chelati Dirar, U. (2008). 'Fedeli servitori della bandiera? Gli ascari eritrei tra colonialismo, anticolonialismo e nazionalismo (1935-1941)'. In L'Impero fascista. Italia ed Etiopia, edited by R. Bottoni, 441-70. Bologna: Il Mulino.

Cipolla, A. 1921. La cometa sulla mummia. Florence: Bemporad.

Corra, B. 1927. Sanya, la moglie egiziana. Milan: Alpes.

Da Verona, G. 1916. Mimì Bluette, fiore del mio giardino. Milan: Baldini e Castoldi.

Da Verona, G. 1920. Sciogli la treccia Maria Maddalena. Florence: Bemporad.

De Donno, F. 2006. 'La razza Ario-Mediterranea'. Interventions 3(7): 394-412.

De Napoli, O. 2009. La prova della razza. Cultura giuridica e razzismo in Italia negli anni Trenta. Florence: Le Monnier.

Decleva, E. 1993. Arnoldo Mondadori. Milan: Mondadori.

Dei Gaslini, M. 1926. Piccolo amore beduino. Milan: L'Eroica.

Dei Gaslini, M. 1928. Natisc, fiore dell'oasi. Bologna: Cappelli.

Deplano, V. 2012. 'Madre Italia, Africa Concubina: la femminilizzazione del territorio nel discorso coloniale fascista'. Genesis 12: 55-73. 
Deplano, V. 2015. L'Africa in casa: propaganda e cultura coloniale nell'Italia fascista. Florence: Le Monnier.

Deplano, V., L. Mari and G. Proglio, eds. 2014. Subalternità italiane. Percorsi di ricerca tra letteratura e storia. Rome: Aracne.

Eco, U. 1979. The Role of the Reader. Explorations in the Semiotics of Texts. Bloomington: Indiana University Press.

Eco, U. 1994. Six Walks in the Fictional Woods. Cambridge (MA): Harvard University Press.

Fabietti, A. 1937. L'amba selvaggia. Avventure sui laghi d'Etiopia. Milan: Genio.

Faloppa, F. 2013. Sbiancare un etiope: la pelle cangiante di un topos antico. Rome: Aracne.

Ferrando, A. 2019. Stranieri all'ombra del duce. Le traduzioni durante il fascismo. Milan: Franco Angeli.

Festa, A. 1931. L'ascaro libico. Racconto di vita coloniale. Florence: Bemporad.

Gabrielli, G. 1997. 'Un aspetto della politica razzista nell'Impero: il problema dei meticci'. Passato e presente 15 (41): 77-105.

Gabrielli, G. 2004-2005. 'Il razzismo coloniale italiano tra leggi e società'. Quaderni Fiorentini 33/34: 343-358.

Gabrielli, R. D. 1928. Il piccolo Brassa. Romanzo coloniale per i giovani. Palermo: Industrie Editoriali Riunite Siciliane.

Galfrè, M. 2005. Il regime degli editori. Libri, scuola e fascismo. Bari-Rome: Laterza.

Gentile, E. (1995) 2018. La via italiana al totalitarismo. Il partito e lo Stato nel regime fascista. Rome: Carrocci.

Gentile, E. 1993. Il culto del littorio. Bari-Rome: Laterza.

Gillette, A. 2001. Racial Theories in Fascist Italy. London-New York: Routledge.

Giocondi, M. 1978. Lettori in camicia nera. Narrativa di successo nell'Italia fascista. Florence-Messina: D'anna editore.

Giuliani, G. 2019. Race, Nation and Gender in Modern Italy. Intersectional Representations in Visual Culture. New York: Palgrave Macmillan.

Giuliani, G. and C. Lombardi-Diop. 2013. Bianco e nero. Storia dell'identità razziale degli italiani. Florence: Le Monnier.

Giuliani Caponetto, R. 2015. Fascist Hybridities: Representations of Racial Mixing and Diaspora Cultures Under Mussolini. New York: Palgrave Macmillan.

Goglia, L. 2005. 'Sulle formazioni fasciste indigene'. In Fascismo e franchismo: relazioni immagini rappresentazioni, edited by M. Di Febo, 173-212. Soveria Mannelli: Rubbettino.

Gramsci, A. 1975. Quaderni del carcere. Turin: Einaudi.

Griffin, R. 2007. Modernism and Fascism. A Sense of a Beginning Under Hitler and Mussolini. New York: Palgrave Macmillan.

Guillaumin, C. 1992. Sexe, race et pratique du pouvoir. L'idée de Nature. Paris: Côté-femmes.

Hall, S. (1973) 1991. 'Encoding/Decoding'. In Culture, Media, Language: Working Papers in Cultural Studies (1972-1979), edited by S. Hall, D. Hobson, A. Lowe and P. Willis, 128-40. London-New York: Routledge.

Hom, S. M. 2019. Empire's Mobius Strip. Historical Echoes in Italy's Crisis of Migration and Detention. Ithaca-London: Cornell University Press.

L'Azione Coloniale. 1931. 'Primo referendum sulla letteratura coloniale italiana', 15 January-26 March.

L'Azione Coloniale. 1933. 'Secondo referendum sulla letteratura coloniale italiana', 15 June-28 September.

Labanca, N. 2002. Oltremare. Storia dell'espansione coloniale italiana. Bologna, Il Mulino.

Lenci, M. 2001. 'Amore nero o amore bianco? Autocensura e pregiudizio razziale nel Congo coloniale di Arnaldo Cipolla'. Studi Piacentini 29: 123-51.

Lombardi-Diop, C. and C. Romeo, eds. 2012. Postcolonial Italy. Challenging National Homogeneity. New York: Palgrave Macmillan

McLean, E.K. 2018. Mussolini's Children. Race and Elementary Education in Fascist Italy. Lincoln-London: University of Nebraska Press.

Milanesi, G. 1913. Anthy. Romanzo di Rodi. Milan: Treves. 
Milanesi, G. 1923a. Figlia di Re. Rome: Stock.

Milanesi, G. 1923b. L'ancora divelta. Milan: Mondadori.

Milanesi, G. 1927a. La sperduta di Allah. Rome: Stock.

Milanesi, G. 1927b. Mar sanguigno. Romanzo del mondo. Rome: Stock (Milan 1918).

Milanesi, G. 1936. Sancta Maria. Milan: Mondadori.

Morone, A. M. 2011. L'ultima colonia. Come l'Italia è tornata in Africa 1950-1960. Bari-Rome: Laterza.

Mudimbe, V. 1988. The Invention of Africa. Gnosis, Philosophy, and the Order of Knowledge. Bloomington: Indiana University Press.

Pagliara, M. 1991. 'Faccetta nera'. In I Best-seller del ventennio. Il regime e il libro di massa, edited by G. De Donato and V. Gazzola-Stacchini, 365-80. Rome: Editori Riuniti.

Pinkus, K. 1995. Bodily Regimes: Italian Advertising Under Fascism. Minneapolis: University of Minnesota Press, 1995.

Pisanty, V. 2006. La Difesa della Razza: antologia 1938-1943. Milan: Bompiani.

Poidimani, N. 2009. Difendere la 'razza': identità razziale e politiche sessuali nel progetto imperiale di Mussolini. Rome: Sensibili alle foglie.

Ponzanesi, S. 2005. 'Beyond the Black Venus. Colonial Sexual Politics and Contemporary Visual Practices'. In Italian Colonialism. Legacies and Memories, edited by J. Andall and D. Duncan, 165-89. Oxford: Peter Lang.

Proglio, G. 2014. 'Subalternità e silenzi tra storia e letteratura. Modelli epistemologici e luoghi della contronarrazione'. In Subalternità italiane. Percorsi di ricerca tra letteratura e storia, edited by V. Deplano, L. Mari and G. Proglio, 81-96. Rome: Aracne.

Proglio, G. 2016. Libia 1911-1912. Immaginari coloniali e italianità. Florence: Le Monnier.

Ricci, L. 2005. La lingua dell'impero. Comunicazione, letteratura e propaganda nell'età del colonialismo italiano. Roma: Carocci.

Said, E. 1978. Orientalism. New York: Pantheon Books.

Santangelo, G.S. 2017. 'Scrivere fra due guerre: riflessi socio-letterari del colonialism italiano'. Verbis 1: 45-72.

Scotto di Luzio, A. 1996. L'appropriazione imperfetta. Editori, biblioteche e libri per ragazzi durante il fascismo. Bologna: Il Mulino.

Sorgoni, B. 1998. Parole e corpi: antropologia, discorso giuridico e politiche sessuali interrazziali nella colonia eritrea, 1890-1941. Naples: Liguori.

Sorgoni, B. 2001. Etnografia e colonialismo. L'Eritrea e l'Etiopia di Alberto Pollera. Milan: Bollati Boringhieri.

Sorgoni, B. 2003. 'Defending the Race: The Italian Re-Invention of the Hottentot Venus'. Journal of Modern Italian Studies, 8, 411-24.

Stefani, G. 2010. 'Bianchi e no. Promiscuità e commistione razziale tra italiani e indigeni nell'impero colonial fascista'. Studi culturali 1: 103-24.

Tarquini, A. 2011. Storia della cultura fascista. Bologna: Il Mulino.

Tedesco Zammarano, V. 1935. Ahuér, mio sogno. Milan: Ceschina.

Tomasello, G. 1984. La letteratura coloniale italiana dalle avanguardie al fascismo. Palermo: Sellerio.

Tomasello, G. 2004. L'Africa tra mito e realtà. Storia della letteratura coloniale italiana. Palermo: Sellerio.

Tranfaglia, N. and A. Vittoria. 2000. Storia degli editori italiani. Dall'Unità alla fine degli anni Sessanta. Bari-Rome: Laterza.

Vergani, O. 1928. Io, povero negro. Milan: Treves.

Zaccaria, M. 2012. Anch'io per la tua bandiera. Il V Battaglione Ascari in missione sul fronte libico (1912). Ravenna: Giorgio Pozza.

Zocchi, B. 2019. 'Italian Colonialism in the Making of National Consciousness: the Representations of African Natives'. Storicamente 14: 1-27.

Zuccoli, L. 1923. Kif tebbi. Milan: Treves. 


\section{Italian summary}

Questo saggio si concentra su alcuni dei dispositivi di razzializzazione attivati all'interno dei romanzi coloniali italiani. Nello specifico, l'analisi si concentra su due romanzi pubblicati nei tardi anni Venti - Un canto nella notte. Romanzo coloniale di Enrico Cappellina e La sperduta di Allah di Guido Milanesi - nel tentativo di evidenziare le continuità e le discontinuità fra i diversi modelli di convivenza razziale propugnati in ciascuna delle due opere. Attraverso l'analisi testuale dei due romanzi ci si propone di sottolineare il grado di interconnessione che intercorre fra interpretazioni inclusiviste e segregazioniste dell'incontro coloniale interrazziale nella prima metà del Ventennio fascista. In questa prospettiva, si suggerisce che la proclamazione dell'Impero nel 1936, per quanto rappresenti un momento di notevole discontinuità a livello legislativo e politico, abbia svolto un ruolo assai meno netto quando visto dalla prospettiva della produzione letteraria. 